\title{
ANTS FROM THREE REMOTE OCEANIC ISLANDS
}

By Robert W. Taylor and Edward O. Wilson

Biological Laboratories, Harvard University

The three islands (Raoul, Clipperton, St. Helena) whose ant faunas are described below have in common only extreme geographic isolation. That ants occur on them at all confirms the idea that these insects, with man's help, have now populated every part of the earth capable of supporting them. These and other remote oceanic islands will undoubtedly attract more of the ecologist's attention in the future, since many animal taxa inhabiting them, including most or all of the ant species, have only arrived within historical times and present simple case histories of faunas in the first stages of local adaptation.

We are grateful to Dr. J. S. Edwards, Dr. C. F. Harbinson, Mr. Arthur Loveridge and Dr. B. A. Holloway of the Dominion Museum, Wellington, New Zealand, for making these unusual collections available. The study has been supported in part by a research grant from the National Science Foundation.

\section{Raoul Island, Kermadec Islands}

The Kermadecs are a group of forest-clad volcanic islands lying in the South Pacific between S. lat., 29.10 and 31.30; and W. long., I 77.45 and I79.0O. The nearest sizable land mass is the North Island of New Zealand, about 650 miles to the southwest, and the nearest. major Polynesian island is Tongatabu of the Tongan group, about 700 miles to the north. Australia lies about I.700 miles to the west.

The ants listed below were taken on Raoul or Sunday Island, the largest of the group (I I.25 sq. miles), or on its tiny outlier, Meyer Island. Most of the material was collected during June 1956 for the University of Auckland, New Zealand, by Dr. J. S. Edwards of Cambridge University. A few records are from the collections of the Museum of Comparative Zoology, Harvard University, or from the Dominion Museum, Wellington, New Zealand. Unless otherwise noted all collections were made by Dr. Edwards.

The collection includes a number of Berlese funnel samples as well as hand-collected specimens, and although only three species are listed, it is thought that they represent most, if not all, those present on Raoul in 1956.

Ponera gleadowi Forel

The systematics and distribution of this ant have been discussed by Wilson (1958). P. gleadowi is a widespread species, originally 
described from India, and found throughout South East Asia, Melanesia and Polynesia. It is apparently native throughout most of its range, but may have been distributed in part by man (i.e., it is a member of "Class II" discussed below).

Material examined: RAOUL ISLAND: June 5, I956; under rock, watercourse, June 8, 1956 (nest with ergatomorphic male pupae); ex Pohutakawa logs (Metrosideros sp.), June 3, I956. Crater: June 4, I956; ex moss caps on pumice boulders, June 4, I956; ex Pohutukawa log, June 4, 1956 (nest with alate queens). Denham Bay: ex Narcissus litter Berlese funnel sample, June 7, 1956. Denham Bay swamp: ex Pohutakawa litter Berlese funnel sample, June 2, I956. Hostel Bay: Berlese funnel sample, June 7, 1956; Coxnocarpus litter Berlese funnel sample, June 8, I956. Oneraki Beach: beneath cow dung under trees, June 9, I956 (J. S. Soeberg). MEYER ISLAND: Berlese funnel samples, June 7, I956; June I6, 1956.

Ponera gleadowi is apparently the most abundant ant on Raoul and was "commonly found (by Dr. Edwards) under stones or in decaying logs or branches, frequently associated with termites." Moreover it was present in about half of the Berlese funnel samples processed by Dr. Edwards. As indicated, winged queens are present in the nests during June. No adult males were located, but several pupae from the nest collected on June 8, 1956, were found to contain almost fully developed ergatomorphic males. Except for genital differences these are similar to the workers, and like them have twelvesegmented antennae.

\section{Tetramorium guineense (Fabricius)}

This is one of the most common pantropical formicid tramp species. It evidently originated in Africa and ranges widely throughout the Old and New World tropics, and Northern Australia. It is widespread in Polynesia (Wheeler, 1935) and has recently been found established near Auckland, New Zealand. Dispersal by man has clearly been of primary importance in the distribution of this species.

Material examined: RAOUL ISLAND: June 4, I956; quarry, under rock, June 5, 1956, (nest with alate females). MEYER ISLAND: Berlese funnel sample, June 7, 1956.

Monomorium antarcticum (White)

At present the name $M$. antarcticum is applied to what is almost certainly a complex of species found in New Zealand and its outlying islands, including the Chatham group, some 470 miles to the east 
of South Island. It has undoubtedly been carried to the Chatham Islands by man (Brown, 1958). (It is further likely that Monomorium rapaënse Wheeler (1936) of Rapa Island in the Austral group, is conspecific with some New Zealand form belonging to the present $M$. antarcticum complex. If this should be so the fact that New Zealand and Rapa were both important whaling ports in the nineteenth century may be significant with regard to the dispersal of this form.)

Material examined: RAOUL ISLAND: Crater: nest in warm soil beside fumarole, June 3, 1956. Four workers without further data from the M. C. Z. collection.

The M. C. Z. specimens were studied by Wheeler in preparing his 1935 paper and were probably collected by the W. R. B. Oliver expedition to Raoul Island during I907-08. Wheeler apparently intended using these specimens as the types of a new species, to be described in a later paper which, however, was never published due to his death. It seems unlikely that they are specifically separate from some North Island samples of the antarcticum complex, and they have almost certainly been introduced to Raoul from New Zealand.

The Kermadec ant fauna is thus characterized by a lack of endemic or native species and includes forms derived either from tropical Polynesia, or the nearest large land area, and known to have capacities for passiva dispersal by man. The faunal tally of only three species is probably well below the possible maximum carrying capacity of the island (see Wilson, I96r). Although the present human settlement on Raoul consists only of the staff of a weather station, there have been several attempts to colon'ze it in the past. The parties concerned are known to have travelled from Fiji and New Zealand, and to have carried much produce as well as plants and seeds, thus providing adequate passage for ants. In its relationships and depauperate nature the ant fauna resembles those of other insect groups which have been studied (see Miller, I956 p. 420 for references).

Some interesting comparisons can be made with the faunas of Lord Howe and Norfolk Islands, which are about the same size as Raoul, and lie at approximately the same latitude, but much closer to Australia.

The ants of these three islands may be grouped for analysis into three classes.

Class $I$. Species which are probably native to the island concerned. This category includes forms found also in Australia, and endemic species (all of which are clearly derived from Australian stock). 
Class II. Species native to, and sometimes widespread in the IndoAustralian region which appear to have been distributed in part by man.

As the islands under discussion are rather peripheral to the main part of the Indo-Australian area it is difficult to estimate whether "Class II" species listed from them are truly native, or whether they have originated from propagules carried by man. This difficulty is especially evident with respect to the Lord Howe and Norfolk Island forms, but in our opinion, it is highly probable that the "Class II" Kermadec species (Ponera gleadowi and Monomorium antarcticum) were carried to Raoul by man.

Class III. Widespread pantropical or cosmopolitan forms well known as "tramp species" and distributed largely by man.

The numbers of species referable to each of these classes on the islands concerned are shown in Table I.

\begin{tabular}{|c|c|c|c|}
\hline South latitude & $\begin{array}{l}\text { Lord Howe } \\
\text { Island } \\
30^{\circ} 30^{\prime}\end{array}$ & $\begin{array}{c}\text { Norfolk } \\
\text { Island } \\
29^{\circ} 4^{\prime}\end{array}$ & $\begin{array}{l}\text { Raoul } \\
\text { Island } \\
29^{\circ}{ }^{\circ} 0^{\prime}\end{array}$ \\
\hline Size $\left(\mathrm{mi}^{2}\right)$ & 5 & 13 & II 25 \\
\hline Distance from & & & \\
\hline $\begin{array}{l}\text { Australia (mi) } \\
\text { No. ants Class I }\end{array}$ & 400 & 900 & 1700 \\
\hline (endemics bracketed) & $\mathrm{IO}(5)$ & $8(\mathrm{I})$ & - \\
\hline No. ants Class II & 3 & I & 2 \\
\hline No. ants Class III & I & 3 & I \\
\hline Total number of ants & I 4 & I 2 & 3 \\
\hline
\end{tabular}

Table I. Certain geographical features of Lord Howe Island, Norfolk Island, and Raoul Island; with details of the class composition of their ant faunas. Further explanation in text [data based in part on Wheeler (1927), modified by recent revisionary studies].

Although native ants are apparently absent from Raoul they are present on both Lord Howe and Norfolk Islands. The species concerned are all of Australian origin, and more of them are present on Lord Howe than on Norfolk, in spite of the considerably larger size of the latter. Faunal size on these islands is thus negatively correlated with their areas, a reverse situation from that observed by Wilson (196I) in various Moluccan and Melanesian Islands. Judging from the Melanesian faunal curves published by Wilson, we believe that Lord Howe Island probably supports a saturated ant fauna. Norfolk Island, however, would be expected to carry more 
species than it does - and considerably more than Lord Howe. The reason for the apparently sub-normal size of the Norfolk Island fauna may be sought in the correlation between faunal size on the two islands and the following two factors:

I. Ecological Diversity: The published reports of the terrain and the state of the vegetation on these islands suggest that Lord Howe is ecologically much more diverse than is Norfolk Island. In spite of its much smaller size it may, therefore, be capable of supporting a larger and more varied ant fauna. Conversely, Norfolk Island may have a lower carrying capacity due to its lower ecological diversity, so that its fauna, although proportionatcly smaller than that of Lord Howe, is nevertheless saturated.

2. Distance from Australia: The apparent correlation between faunal sizes on these islands and their distances from Australia contrasts with Wilson's (I96I) finding in Melanesia, where such correlation is lacking. 'This situation may be due to the absence of intermediate islands between those under discussion and Australia islands which might provide assistance as "stepping stones" to colonists. According to this hypothesis the small size of the Norfolk ant fauna is due to the fact that too few species have reached the Island to saturate its carrying capacity.

If mere distance from Australia does have the filtering effect envisaged it may be assumed that there is a maximum range of natural overseas dispersal of the Australian fauna. As far as the ants are concerned, Raoul, in lacking indigenous Australian elements, may be considered to be outside this range.

It is not possible, at present, to evaluate the relative importance of these two factors in determining the size of the Norfolk Island ant fauna, but the problem would certainly be worthy of attention by future field workers in these areas.

Lord Howe Island also has significantly more cndemic ant species than has Norfolk; each of these represents a stock which has diverged from its Australian progenitor and in no case has splitting or radiation taken place in situ on the island. The ecological diversity of the island, coupled with the competitive pressures which must arise in such a dense fauna, has probably caused this specialization of stocks, with consequ'nt phyletic change to the point of formation of an endemic species in some lineages.

\section{Clipperton IsLAND}

Clipperton Island is a lonely coral atoll about four miles in diameter, lying at N. lat., IO.I8 and W. long., I09.I 5. It is I,800 
miles due west of the Panama Canal, and about 670 miles southwest of the nearest part of the Mexican coast. Most of the island is barely io feet high, but it rises to about 70 feet at one point. The vegetation consists of grasses, shrubs, and wild tobacco and there are several coconut groves.

The island is now uninhabited but it was occupied by a Mexican garrison from 1879-1917, and by about IOO phosphate miners from I906-19I7. Both of these groups received regular supplies from Mexico. Clipperton was occupied by the United States Navy during the Second World War.

The ants listed below were collected for the Museum of Comparative Zoology by A. M. Peterson and C. F. Harbinson during August 1958; the collection is almost certainly fully representative.

Odontomachus insularis (Guérin)

This species is widespread in Central America and the West Indies, and ranges north to Florida and Georgia. It also occurs on Cocos Island and the Tres Marias Islands in the Eastern Pacific. It is noteworthy that the Island of Clarion in the Revillagigedo group is occupied by a second species, O. clara Roger (=haematoda clarionensis Wheeler), which is widespread in Mexico and the West Indies. A third far ranging species, O. bauri Emery (=haematoda div. auct.; nec haematoda L.?), occurs on the Galapagos. All of these exclusively New World species are to be distinguished from the closely similar Indo-Australian $O$. simillimus $\mathrm{Fr}$. Smith, (=haematoda div. auct.; nec haematoda L.), which ranges eastwards only to Tahiti. Three series collected.

Tetramorium simillimum (Fr. Smith)

Like $T$. guineense this is a pantropical tramp species of African origin, widespread both in Central America and Polynesia. Its total range closely approximates that of guineense. Ten series collected. Triglyphothrix striatidens (Emery).

A species of tropical Oriental origin, spread by commerce throughout the Pacific, and established in North Africa and Queensland, Australia. Seven series collected.

Like Raoul, Clipperton has a depauperate ant fauna, consisting cntirely of species which have probably been introduced by man.

\section{Saint Helena Island}

Saint Helena (S. lat., I 5.57, W. long., 5.42) is a small volcanic island $47 \mathrm{sq}$. miles in area, lying in the south Atlantic about I,800 
miles from South America, and I,200 miles from Africa. The Island differs in several respects from those discussed above, in that it is well populated and is visited more regularly by shipping. Indeed, it has at times been a major port-of-call for trade between Europe, and South Africa and India. The ants listed below have probably all been introduced to the island by man. They were collected for the Museum of Comparative Zoology between 1958 and I960 by Mr. Arthur Loveridge. The collection is probably less representative than those already discussed, so that no faunal analysis can be attempted at present.

Tetramorium simillimum (Fr. Smith)

The distribution of this species has been discussed above. One series collected at Varneys.

Pheidole megacephala (Fabricius)

This is one of the most widespread and notorious of the commercial tramp ant species, it is now virtually cosmopolitan in warm humid areas. Sandy Bay: under rocks. Prosperous Bay: nest with alates, under rocks, February 24, 1958. Varneys: alate males from a storeroom cabinet, February 19, 1960.

Solenopsis (Diplorhoptrum) sp.

The subgenus Diplorhoptrum includes a number of taxonomically confused, and in some cases widespread, cryptobiotic species, several of which appear to be commercial tramps. A single series labeled Varneys, IOOO feet.

Plagiolepis alluaudi Forel

This species, probably of East African origin, is a widespread pantropical tramp species. A single series from Varneys.

Paratrechina bourbonica Forel

A widespread pantropical tramp species, apparently of African origin. A single series from Varneys.

BROWN, W. L., JR.

\section{REFERENCES}

1958. A review of the ants of New Zealand (Hymenoptera-Formicidae). Miller, David Acta Hym., (Fukuoka), 1 (1): 1-50.

1956. Bibliography of New Zealand Entomology. 1775-1952. Bull. N. Z. WHEELER, W. M. Dept. Sci. Ind. Res., 120 : 1-492.

1927. The ants of Lord Howe Island and Norfolk Island. Proc. Amer. Acad. Arts Sci., 62: 121-153.

1935. Checklist of the ants of Oceania. Occ. Pap. Bishop Mus., 11 (11): $1-56$. 
1936. Ants from the Society, Austral, Tuamotu and Mangareva Islands. Occ. Pap. Bishop Mus., 12 (18) : 1-17.

WiLson, E. O.

1958. Studies on the ant fauna of Melanesia. IV. The tribe Ponerini. Bull. Mus. Comp. Zool. Harvard, 119 (4): 320-371.

1961. The nature of the taxon cycle in the Melanesian ant fauna. American Naturalist, 95 (882): 169-193. 

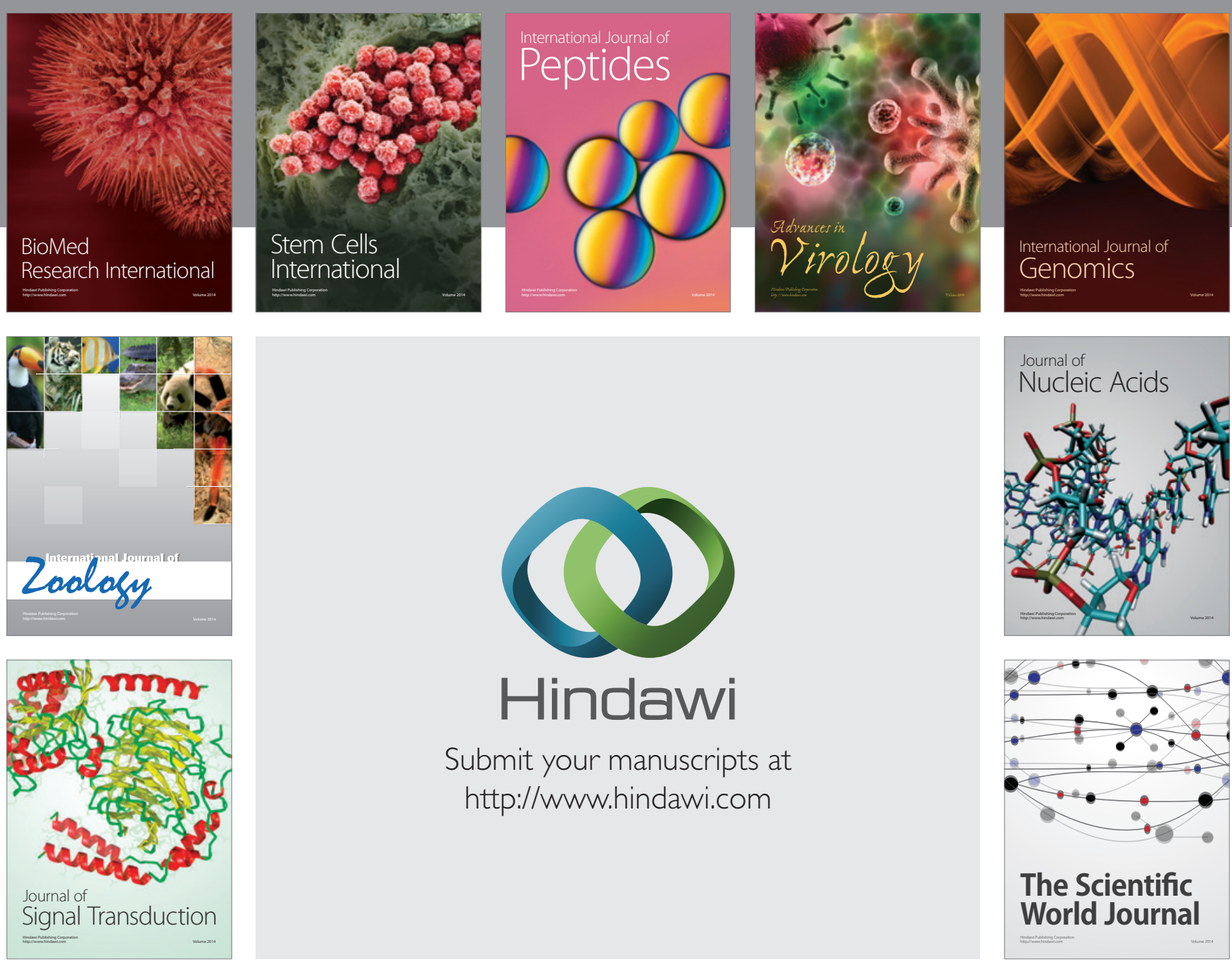

Submit your manuscripts at

http://www.hindawi.com
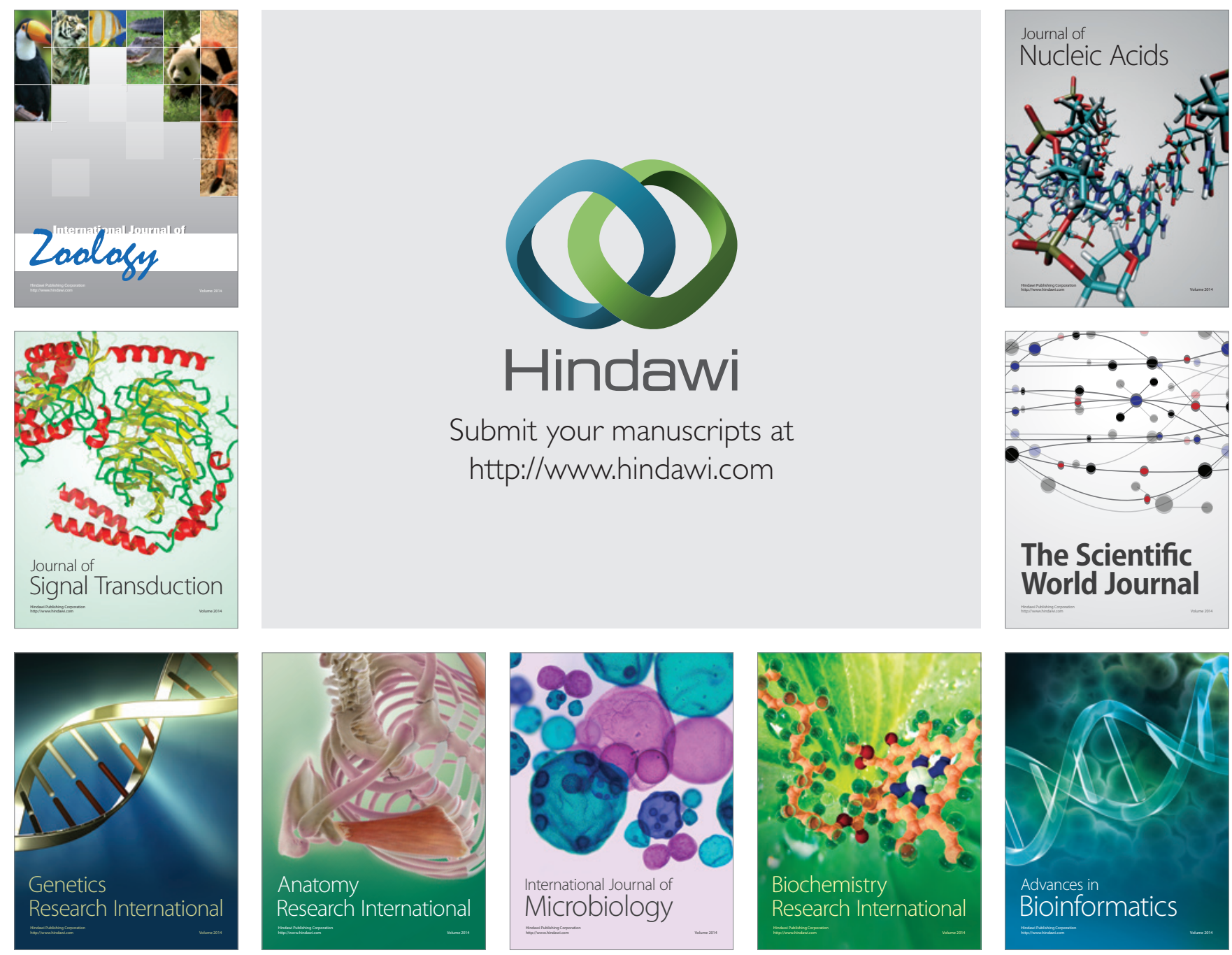

The Scientific World Journal
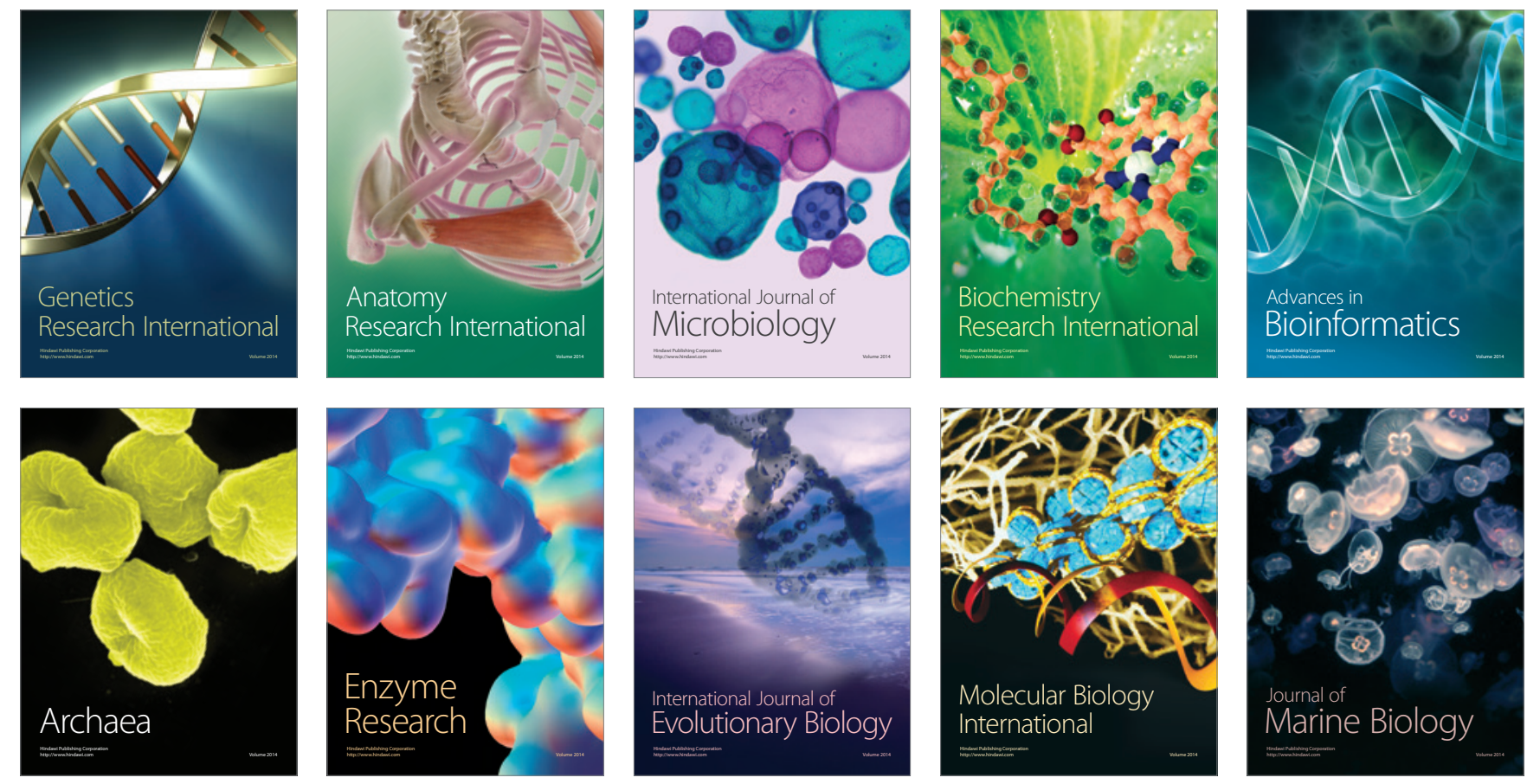